Brit. J. vener. Dis. (1957), 33, 25.

\title{
COMPARISON OF RESULTS GIVEN BY A COMPLEMENT-FIXATION TEST FOR SYPHILIS USING THE REITER TREPONEME AS ANTIGEN WITH THE TREPONEMAL IMMOBILIZATION TEST*
}

\author{
BY \\ A. E. WILKINSON \\ V.D. Reference Laboratory (M.R.C.), London Hospital Research Laboratories, London
}

Although the treponemal immobilization test (TPI) is now generally accepted as being a sensitive and highly specific test for treponemal disease, difficulties in its execution have restricted its performance to specialized laboratories. Alternative methods of demonstrating specific antibodies by agglutination, immune adherence, and complementfixation tests with virulent treponemes or extracts have been used, but as the yield of antigen from the testes of infected rabbits is relatively small, the use of these tests as routine serological procedures has not hitherto been practicable.

The interest which the TPI and similar tests aroused has tended to distract attention from complement-fixation tests for syphilis which use suspensions of the Reiter trepomene as antigen. The serological properties of this organism, which can be grown in simple culture media, have been extensively investigated by the Italian group of workers led by D'Alessandro and Puccinelli, who have presented very favourable reports on its use in the serological diagnosis of syphilis. By the use of this organism, antibodies can be detected in syphilitic sera which are distinct from the reagin(s) whose presence is shown by the serum tests for syphilis (STS) using alcoholic extracts of tissue lipoids as antigens. Because of this, the Reiter antigen is thought to be more specific than the classical tests using lipoidal antigens.

In this investigation, parallel tests have been carried out on sera with three STS: Wassermann reaction (WR) with a crude heart extract antigen, the Kahn test, and Price's precipitation reaction (PPR); a complement-fixation test using a suspension of the Reiter treponeme as antigen (RCFT); and the TPI test. Because of its high specificity, the latter has been used as the index for comparison between the other tests.

\footnotetext{
* Received for publication January 29, 1957.
}

\section{Methods}

Upon receipt in the laboratory, sera were split into two specimens, one being used for the WR, Kahn test, and PPR, while the second was kept at $-20^{\circ} \mathrm{C}$. until the TPI and RCFT could be carried out.

The technique used for the RCFT followed that of the standard WR used in this laboratory (Price, 1950). The treponeme suspension in $\mathbf{0} \cdot \mathbf{3}$ per cent. phenol-saline was used undiluted; it was slightly anticomplementary and careful adjustment of the haemolytic system was necessary. After standing in the refrigerator at 4 to $6^{\circ} \mathrm{C}$. the organisms tended to sediment out; before being used, the antigen was shaken on a Kahn shaker for 5 to 10 min. to ensure an even suspension of the treponemes. The tests were incubated for an hour at $37^{\circ} \mathrm{C}$. before the addition of sensitized cells and read after a further 30 min. at $37^{\circ} \mathrm{C}$. The PPR was performed by the original method (Price, 1948), while the TPI technique was that of Nelson and Mayer (1949) with the minor modifications described by Wilkinson (1954).

\section{Material}

I. Sera from Patients with Symptomatic Syphilis Primary or secondary, 58; late, 79; congenital, 59.

II. Problem Sera sent to the V.D. Reference Laboratory for Checking.--These came from the four following groups of patients:

(a) 270 pregnant women and 72 blood donors who had been found sero-positive on routine testing.

(b) 216 patients with suspected latent syphilis.

(c) 218 patients with negative or equivocal STS reactions who had lesions or histories suggestive of syphilis.

(d) 36 patients with conditions which are frequently associated with non-specific STS reactions, e.g., lupus erythematosus, acquired haemolytic anaemia.

In many instances, tests were carried out on more than one specimen of serum from the same patient. To avoid duplication of results only the results of tests on the first specimen examined are considered. 
A small number of sera had to be excluded from the survey as they were toxic or anticomplementary in the TPI or complement-fixation tests. To simplify the presentation, doubtful results (which were confirmed by repetition on the same specimen of serum) have been included among the positive results.

\section{Results}

\section{Sera from Patients with Symptomatic Syphilis}

The number of patients in each group is too small to warrant very definite conclusions, but the results shown in Tables I, II, and III are in fair agreement with those of other workers. In untreated early syphilis the RCFT was the most sensitive test and in three cases of dark-ground positive primary syphilis was the only test giving a positive result. Similarly, in the patients with late symptomatic syphilis, its sensitivity was appreciably higher than that of the other STS. In sera from congenital syphilitics, however, its sensitivity was well below that of the other STS; most of these patients were adolescents or adults and it was noted that twelve out of 26 patients who had been treated in the past gave negative RCFT reactions. In contrast, only three out of thirteen who had not been treated were negative with this test.

TABLE I

RESULTS OF PARALLEL TESTS ON SERA FROM 58 PATIENTS WITH EARLY (PRIMARY OR SECONDARY) SYPHILIS

\begin{tabular}{c|c|c|c|c}
\hline \multirow{2}{*}{ Test } & \multicolumn{2}{|c|}{ Untreated } & \multicolumn{2}{|c}{ Treated } \\
\cline { 2 - 5 } & Positive & Negative & Positive & Negative \\
\hline WR & 16 & 13 & 13 & 16 \\
Kahn & 20 & 9 & 19 & 10 \\
PPR & 16 & 13 & 14 & 15 \\
RCFT & 23 & 6 & 13 & 16 \\
TPI & 17 & 12 & 19 & 10 \\
\hline
\end{tabular}

TABLE II

RESULTS OF PARALLEL TESTS ON SERA FROM 79 PATIENTS WITH LATE SYMPTOMATIC SYPHILIS

\begin{tabular}{c|c|c}
\hline Test & Positive & Negative \\
\hline WR & 55 & 24 \\
Kahn & 56 & 23 \\
PPR & 53 & 26 \\
RCFT & 63 & 16 \\
TPI & 78 & 1 (Tabes, with \\
& & Charcot joint) \\
\hline
\end{tabular}

TABLE' III

RESULTS OF PARALLEL TESTS ON SERA FROM 59 PATIENTS WITH CONGENITAL SYPHILIS

\begin{tabular}{c|c|c}
\hline Test & Positive & Negative \\
\hline WR & 46 & 13 \\
Kahn & 47 & 12 \\
PPR & 46 & 13 \\
RCFT & 39 & 20 \\
TPI & 53 & 6 \\
\hline
\end{tabular}

A baby, who showed evidence of passive transfer of maternal antibodies, was followed up by serial tests (Table IV). The mother, who was also TPIpositive, had not been treated during her pregnancy as she was first tested when at term. The short life of the RCFT antibody in the child's circulation compared with the persistence of the immobilizing antibody is noteworthy.

TABLE IV

SERIAL TESTS ON A BABY SHOWING PASSIVE TRANSFER OF MATERNAL ANTIBODIES

\begin{tabular}{c|c|c|c|c|c|c}
\hline $\begin{array}{c}\text { Age } \\
\text { (wks) }\end{array}$ & WR & CWR* & Kahn & PPR & RCFT & $\begin{array}{c}\text { TPI (per } \\
\text { cent S.I.)t }\end{array}$ \\
\hline 1 & + & + & + & + & & \\
4 & 0 & + & + & 0 & & \\
9 & 0 & + & + & 0 & + & Pos. 100 \\
14 & 0 & 0 & 0 & 0 & 0 & Pos. 96 \\
28 & 0 & 0 & 0 & 0 & 0 & Pos. 65 \\
53 & 0 & 0 & 0 & 0 & 0 & Neg. 10 \\
\hline
\end{tabular}

* WR with cardiolipin antigen.

† S.I. $=$ specific immobilization.

\section{Tests on "Problem" Sera}

These sera are selected to an unknown extent, as those giving weakly positive or discordant results would be more likely to be referred for confirmatory testing than those giving strongly positive reactions. The results may thus not be representative of the classes of patients discussed.

(a) Sera from Pregnant Women and Blood Donors.-These patients had been found seropositive on routine testing. A number had been treated on the basis of these results and an immobilization test was asked for to confirm the original diagnosis. The results of the parallel tests are shown in Tables V and VI. In these and subsequent Tables the TPI test is used as the standard for comparison of the other tests.

TABLE V

RESUlTS OF PARALLEL TESTS ON SERA FROM 270 PATIENTS FOUND TO BE POSITIVE ON ROUTINE ANTENATAL TESTING

\begin{tabular}{|c|c|c|c|c|c|}
\hline Test & \multicolumn{2}{|c|}{ Agreement } & \multicolumn{3}{|c|}{ Disagreement } \\
\hline $\begin{array}{l}\text { TPI } \\
\text { STS }\end{array}$ & + & $\begin{array}{l}\mathbf{0} \\
\mathbf{0}\end{array}$ & + & $\begin{array}{l}0 \\
+\end{array}$ & \\
\hline \multirow[b]{2}{*}{$\begin{array}{c}\text { WR } \\
\text { Kahn } \\
\text { PPR } \\
\text { RCFT }\end{array}$} & \multirow[b]{2}{*}{$\begin{array}{l}178 \\
170 \\
167 \\
166\end{array}$} & \multirow[b]{2}{*}{$\begin{array}{l}50 \\
47 \\
53 \\
73\end{array}$} & \multirow[b]{2}{*}{$\begin{array}{r}9 \\
17 \\
20 \\
21\end{array}$} & No. & Per cent. \\
\hline & & & & $\begin{array}{l}33 \\
36 \\
30 \\
10\end{array}$ & $\begin{array}{r}12 \cdot 2 \\
13 \cdot 3 \\
11 \cdot 1 \\
3 \cdot 7\end{array}$ \\
\hline
\end{tabular}

Table $\mathrm{V}$ shows that the RCFT was in closer agreement with the TPI test than were any of the other STS. Its sensitivity was about equal to that of the two flocculation tests but slightly below that of the WR. Its specificity, as judged by the positive reactions which were not confirmed by a positive 
TPI result, was greater than any of the STS. Only ten patients $(3.7$ per cent.) gave this pattern of results, as compared with $11 \cdot 1$ to 13.3 per cent. with the other STS. Five of these ten patients had been treated; only two gave an isolated positive RCFT, five gave positive results with all three STS, and in the remaining three the STS results were discordant. The husband of one of these patients was known to be sero-positive.

The results of tests on 72 patients who had been found sero-positive as blood donors are shown in Table VI. In this group the sensitivity of the RCFT equalled that of the other STS, whereas, judged by the TPI results, it was considerably more specific, only two sera giving a positive RCFT which was not confirmed by the TPI result. One of these two patients had been treated some years previously and all three STS were strongly positive; in the other case only the WR was positive.

TABLE VI

RESULTS OF PARALLEL TESTS ON 72 PATIENTS FOUND TO BE SERO-POSITIVE AS BLOOD DONORS

\begin{tabular}{|c|c|c|c|c|c|}
\hline Test & \multicolumn{2}{|c|}{ Agreement } & \multicolumn{3}{|c|}{ Disagreement } \\
\hline $\begin{array}{l}\text { TPI } \\
\text { STS }\end{array}$ & $\begin{array}{l}+ \\
+\end{array}$ & $\begin{array}{l}0 \\
0\end{array}$ & $\stackrel{+}{0}$ & $\begin{array}{l}0 \\
+\end{array}$ & \\
\hline & & & & No. & Per cent. \\
\hline $\begin{array}{c}\text { WR } \\
\text { Kahn } \\
\text { PPR } \\
\text { RCFT }\end{array}$ & $\begin{array}{l}42 \\
44 \\
41 \\
45\end{array}$ & $\begin{array}{r}9 \\
6 \\
12 \\
20\end{array}$ & $\begin{array}{l}8 \\
6 \\
9 \\
5\end{array}$ & $\begin{array}{r}13 \\
16 \\
10 \\
2\end{array}$ & $\begin{array}{r}18 \\
22 \\
14 \\
3\end{array}$ \\
\hline
\end{tabular}

(b) Sera from Patients with Suspected Latent Syphilis.-These patients showed no clinical evidence of syphilis but had been found sero-positive with the STS. Both treated and untreated cases are included and the results compared in Table VII.

TABLE VII

RESULTS OF PARALLEL TESTS ON SERA FROM 216 PATIENTS WITH SUSPECTED LATENT SYPHILIS

\begin{tabular}{|c|c|c|c|c|c|}
\hline Test & \multicolumn{2}{|c|}{ Agreement } & \multicolumn{3}{|c|}{ Disagreement } \\
\hline $\begin{array}{l}\text { TPI } \\
\text { STS }\end{array}$ & + & $\begin{array}{l}0 \\
0\end{array}$ & $\stackrel{+}{0}$ & $\begin{array}{l}0 \\
+\end{array}$ & \\
\hline & & & & No. & Per cent. \\
\hline $\begin{array}{c}\text { WR } \\
\text { Kahn } \\
\text { PPR } \\
\text { RCFT }\end{array}$ & $\begin{array}{l}156 \\
159 \\
150 \\
163\end{array}$ & $\begin{array}{l}13 \\
12 \\
15 \\
25\end{array}$ & $\begin{array}{l}29 \\
26 \\
35 \\
22\end{array}$ & $\begin{array}{r}18 \\
19 \\
16 \\
6\end{array}$ & $\begin{array}{l}8 \\
9 \\
7 \\
3\end{array}$ \\
\hline
\end{tabular}

In this group the RCFT was slightly more sensitive than the other STS and gave only six positive results in TPI-negative sera. All six patients had been treated and in five the other STS were all positive. In the remaining patient, the Kahn test alone was positive and the RCFT gave only partial fixation.
In 57 patients in this group, the diagnosis of latent syphilis rested on other evidence in addition to the serological findings, such as the birth of congenitally syphilitic children or the fact that the patients' consorts were sero-positive or showed clinical evidence of syphilis. The TPI test was positive in all save one case, viz. a woman who had borne a congenitally syphilitic child and had been treated in the past. Her serum gave negative results with all the tests used. Out of the 56 TPI-positive sera, 46 were positive with the RCFT, and 46 with one or more of the STS. Six out of the ten patients giving negative RCFT results had been treated.

In 77 patients not included in Table VII, the STS had been found positive on routine testing, either while in hospital with diseases other than syphilis, or when tested before marriage or emigration. Details are given in Table VIII. In these patients the RCFT was less sensitive than the other STS, but in contrast it was more specific, giving only two results presumed to be non-specific because of the finding of a negative TPI test. One of these occurred in a pre-marital test, and the other in a girl of 13 with vulvo-vaginitis whose serum gave partial fixation in the RCFT.

TABLE VIII

RESULTS OF PARALLEL TESTS ON SERA FROM 77 PATIENTS FOUND TO BE SERO-POSITIVE ON ROUTINE TESTING

\begin{tabular}{|c|c|c|c|c|c|}
\hline Test & \multicolumn{2}{|c|}{ Agreement } & \multicolumn{3}{|c|}{ Disagreement } \\
\hline $\begin{array}{l}\text { TPI } \\
\text { STS }\end{array}$ & + & $\begin{array}{l}0 \\
0\end{array}$ & $\stackrel{+}{0}$ & $\begin{array}{l}0 \\
+\end{array}$ & \\
\hline & & & & No. & Per cent. \\
\hline $\begin{array}{c}\text { WR } \\
\text { Kahn } \\
\text { PPR } \\
\text { RCFT }\end{array}$ & $\begin{array}{l}43 \\
43 \\
40 \\
35\end{array}$ & $\begin{array}{l}20 \\
14 \\
24 \\
28\end{array}$ & $\begin{array}{r}4 \\
4 \\
7 \\
12\end{array}$ & $\begin{array}{r}10 \\
16 \\
6 \\
2\end{array}$ & $\begin{array}{r}13 \\
21 \\
8 \\
3\end{array}$ \\
\hline
\end{tabular}

(c) Patients with Lesions possibly due to Syphilis.These patients had lesions which could be caused by syphilis (e.g., aortitis) or histories suggestive of past syphilis, and their STS were either negative or inconclusive. The results are given in Table IX.

TABLE IX

RESULTS OF PARALLEL TESTS ON SERA FROM 218 PATIENTS WITH LESIONS OR HISTORIES POSSIBLY ATTRIBUTABLE TO SYPHILIS

\begin{tabular}{|c|c|c|c|c|c|}
\hline Test & \multicolumn{2}{|c|}{ Agreement } & \multicolumn{3}{|c|}{ Disagreement } \\
\hline $\begin{array}{l}\text { TPI } \\
\text { STS }\end{array}$ & $\begin{array}{l}+ \\
+\end{array}$ & $\begin{array}{l}0 \\
0\end{array}$ & $\stackrel{+}{0}$ & $\begin{array}{l}0 \\
+\end{array}$ & \\
\hline & & & & No. & Per cent. \\
\hline $\begin{array}{c}\text { WR } \\
\text { Kahn } \\
\text { PPR } \\
\text { RCFT }\end{array}$ & $\begin{array}{l}41 \\
46 \\
38 \\
38\end{array}$ & $\begin{array}{l}136 \\
136 \\
142 \\
143\end{array}$ & $\begin{array}{l}20 \\
15 \\
23 \\
23\end{array}$ & $\begin{array}{l}21 \\
21 \\
15 \\
14\end{array}$ & $\begin{array}{r}10 \\
10 \\
7 \\
6\end{array}$ \\
\hline
\end{tabular}


The RCFT was slightly less sensitive than the WR or Kahn test, but, as judged by the TPI test, had a higher specificity than either. The fourteen RCFT-positive cases whose TPI tests were negative included four patients with aortitis, four with a past history of treated syphilis, one with a healing genital lesion which had been treated with penicillin, and a prostitute whose WR and Kahn test were positive.

(d) Patients Suffering from Conditions which may be Associated with Non-specific STS Reactions.This group comprised fourteen patients with lupus erythematosus, nine with haemolytic anaemia of the acquired type, seven with leprosy, one with polyarteritis nodosa, and five with miscellaneous haematological disorders. The majority of the sera had been found sero-positive elsewhere, but some cases which showed no serological evidence of syphilis with the STS were included. The results are shown in Table X.

TABLE $X$

RESUlTS OF PARALLEL TESTS ON 36 SERA FROM PATIENTS SUFFERING FROM CONDITIONS FREQUENTLY ASSOCIATED WITH NON-SPECIFIC STS REACTIONS

\begin{tabular}{c|c|c|c|c}
\hline Test & Agreement & \multicolumn{2}{|c}{ Disagreement } \\
\cline { 2 - 5 } TPI & + & 0 & + & 0 \\
STS & + & 0 & 0 & + \\
\hline WR & 8 & 14 & 0 & 14 \\
Kahn & 8 & 9 & 0 & 19 \\
PPR & 8 & 12 & 0 & 16 \\
RCFT & 8 & 23 & 0 & 5 \\
\hline
\end{tabular}

The RCFT was in much closer agreement with the TPI than any other of the STS. The eight sera in which both RCFT and TPI were positive all gave strongly positive reactions with the STS; one came from a patient with lupus erythematosus who was a possible congenital syphilitic and two other patients had been treated for syphilis in the past, one on serological grounds only. Five patients showed presumed non-specific reactions with the RCFT: three cases of haemolytic anaemia, one of leprosy, and one of lupus erythematosus. The STS showed almost three to four times as many such reactions.

\section{Discussion}

Although suspensions of cultivable treponemes have long been used as antigens in the hope of detecting specific antibodies in syphilitic sera, their antigenic relationship to virulent $T$. pallidum is still not clear. Beck (1939) compared the reactivity of three cultivable strains (Reiter 36, Kazan II, and Króo) and a strain of mouth spirochaetes with syphilitic and normal sera, and showed that the Kazan and Reiter strains were the most sensitive, while the Reiter strain was the most specific, giving only 0.6 per cent. of reactions which were considered to be non-specific. The strain of mouth spirochaetes was the least sensitive and least specific of those he examined. Rabbits inoculated with the Reiter organism produce antibodies to a high titre against the homologous strain, but they do not produce immobilizing antibodies against the virulent Nichols strain of $T$. pallidum (Khan, Nelson, and Turner, 1951), and the animals are not protected against subsequent infection with syphilis (Gelperin, 1951).

Work on the chemical fractionation of the Reiter organism and its application to serological diagnosis has been reviewed by D'Alessandro, Oddo, Comes, and Dardanoni (1949), Puccinelli (1951 a, b), and D'Alessandro and Dardanoni (1953). Four fractions have been prepared, a thermolabile protein, a thermostable polysaccharide, and two lipoid fractions, one of which appears to react with the "reagin" detected by the classical STS which use tissue extract antigens. The protein and polysaccharide fractions are thought to react with specific anti-treponemal antibodies in syphilitic sera. The necessity for removing the lipoidal antibody from the sera to be tested has been avoided by the use of a strain of the Reiter organism in which the lipoidal fraction is thought to be antigenically inert (Puccinelli and Pezzi, 1949). Inoculation of man with this strain produces antibodies reacting with the protein and polysaccharide Reiter fractions but not with lipoidal antigens (Puccinelli and Bellone, 1949).

Although there are definite serological differences between the Reiter organism and virulent $T$. pallidum, the high specificity of suspensions of the former organisms as antigens for the sero-diagnosis of syphilis suggests strongly that there are antigenic components common to the two organisms. It seems, however, that the relationship between them is not sufficiently close to justify the term "serological twins" applied by D'Alessandro, Oddo, Comes, and Dardanoni (1949).

Comparisons between the Reiter CFT and the TPI have been reported by Bénazet, Brottes, Thivolet, and Sohier (1954), Sohier, Benazet, Brottes, and Thivolet (1954), Hardy, Bornand, and Durel (1955), and Gastinel, Vaisman, and Hamelin (1956). These authors agree that the Reiter CFT is both more sensitive and more specific than the other STS used. Ruge (1956) has also reported the results of parallel tests in 707 reactive sera, some of which were checked by the TPI test; he found the Reiter CFT to compare favourably in sensitivity and specificity with the STS. The results of the present study are in agreement with the reports cited above, and the Reiter CFT results were found to be 
in much closer agreement with those of the TPI test than with the STS. A large proportion of the sera tested were "problem" sera in which a relatively high incidence of non-specific STS reactions might be expected; as judged by the TPI test, the Reiter CFT was found to be more specific than any of the three standard STS which were used. The results with known syphilitic sera suggested that it was more sensitive than the STS, especially in late symptomatic and untreated early syphilis. In congenital syphilis, however, the RCFT was found to be less sensitive than the STS; this agrees with the results of Puccinelli and Vivarelli (1950).

In routine serum testing the combination of a complement-fixation and a flocculation test using tissue extract antigens is customary. Both tests detect the same type of antibody, reagin, and it is suggested that the diagnostic value of serological testing for syphilis would be increased by the inclusion of the Reiter CFT in the battery of tests used.

\section{Summary}

(1) Parallel tests have been carried out on 1,085 sera with the treponemal immobilization test, a complement-fixation test using the Reiter treponeme as antigen, the Wassermann reaction, Kahn test, and Price's precipitation reaction.

(2) In tests on syphilitic sera, the Reiter CFT was found to be more sensitive than the STS in untreated early syphilis and in latent or late symptomatic syphilis.

(3) In "problem" sera, the results of the Reiter CFT were in closer agreement with those of the TPI test than with the STS. Its specificity was higher than any of the STS when judged by the TPI results.

My thanks are due to Professor Vittorio Puccinelli who very kindly provided the Reiter treponeme suspensions with which these tests were carried out.

\section{REFERENCES}

Beck, A., (1939). J. Hyg. (Lond.), 39, 298.

Bénazet, F., Brottes, H., Thivolet, J., and Sohier, R. (1954). Ann. Inst. Pasteur, 86, 674.

D'Alessandro, G., Oddo, F., Comes, R., and Dardanoni, L. (1949). Riv. Ist. sieroter. ital., 24, 134.

D'Alessandro, G., and Dardanoni, L. (1953). Amer. J. Syph., 37, 137. Gastinel, P., Vaisman, A., and Hamelin, A. (1956). Ann. Inst. Pasteur, 90, 249 .

Gelperin, A. (1951). Amer. J. Syph., 35, 1.

Hardy, N., Bornand, G., and Durel, P. (1955). Bull. Soc. franç.

Khan, A. S., Nelson, R. A., and Turner, T. B. (1951). Amer. J. Hyg., 53, 296.

Nelson, R. A. and Mayer, M. M. (1949). J. exp. Med., 89, 369.

Price, I. N. O. (1948). J. clin. Path., 1, 91.

-11950). British Journal of Venereal Diseases, 26, 172.

Puccinelli, V. A. (1951a). "Atti XXXVIII Congr. Soc. ital. Derm. Sif.", vol. 2 , p. 5.

- (195i b). Amer. J. Syph., 35, 340.

Puccinelli, V.A., and Bellone, A. G. (1949). Giorn. ital. Derm. Sif., 90,362 .

and Pezzi, R. (1949). Ibid., 90, 229

- and Vivarelli, I. (1950). Ibid., $91,529$.

Ruge, H. G. S. (1956). British Journal of Venereal Diseases, 32, 242.

Sohier, R., Benazet, F., Brottes, H., and Thivolet, J., (1954). Rev. lyon. Méd., 3, 749 .

Wilkinson, A. E. (1954). British Journal of Venereal Diseases, 30, 144. 